areas to a greater extent than do the stellate cells of the visual cortex.

Institute of Ophthalmology,

R. F. Fisher

University of London, Judd St., London.

${ }^{1}$ Cajal, Ramón y, La Rétine des Vertébrés, 119 (1933).

${ }^{2}$ Dogiel, A. S., Arch.f. Mikrosk. Anat., 41, 62 (1893).

- Polyak, S. L., The Retina (1941).

Oshinomi, T., Act. Soc. Ophthalm. Jap., 34, 881 (1930).

5 Kolmer, W., Handb. d. Mikrosk, Anat. d. Menschen, 3, part 2, 295 (1936).

- Sorsby, A., Brit. J. Ophthalm., 28, 20 (1939).

'Sholl, D. A., J. of Anat., 87, 444 (1953).

\section{Delayed Onset of Proteinuria in Ageing Hypophysectomized Rats}

THE excretion of protein in the urine of the maje rat increases progressively with age $e^{1-3}$, the output of protein approximately doubling with each increase of 200 days in age $^{3}$. This rising level of proteinuria in the rat has been associated with the gradual development of chronic nephrosis with advancing age ${ }^{4}$.

It has been shown by Goodman et al. ${ }^{5}$ that hypophysectomy diminishes spontaneous proteinuria in the young male rat. The present investigation was undertaken to determine whether hypophysectomy performed in early life would permanently restrain the development of proteinuria in the ageing male rat.

At the age of 50 days, a group of 25 male albino rats of the Wistar strain were hypophysectomized using the parapharyngeal approach. Only hypophysectomized animals which gained less than $30 \mathrm{~g}$ in 300 days were used in this study. A second group of 25 male rats of the same age acted as controls. All animals were housed in airconditioned rat quarters $\left(27^{\circ} \pm 1^{\circ} \mathrm{C}\right.$ and $55 \pm 5$ per cent relative humidity) and fod a pelleted diet as described earlier ${ }^{6}$. The urinary excretion of protein was determined a few days before operation and then at the ages of 250 , 400,500 and 600 days. For these estimations rats were placed individually in metabolism cages, and, after an adaptation period of three days, urine was collected for $24 \mathrm{~h}$. Urinary protein was estimated using the trichloroacetic acid turbidimetric method of Henry et al. ${ }^{7}$.

At the age of 600 days only 6 hypophysectomized and 23 control rats survived. Protein excretion data from these animals at various ages are shown in Fig. 1. In the 23 control rats the mean protein excretion rose from zero at 48 days to $6.2 \mathrm{mg} \mathrm{N}$ per day at 600 days. However, in the 6 hypophysectomized rats no protein was excreted in urine until they were 500 days old, when trace amounts $(0.1 \mathrm{mg} /$ day) were detected in 3 animals. At 600 days these

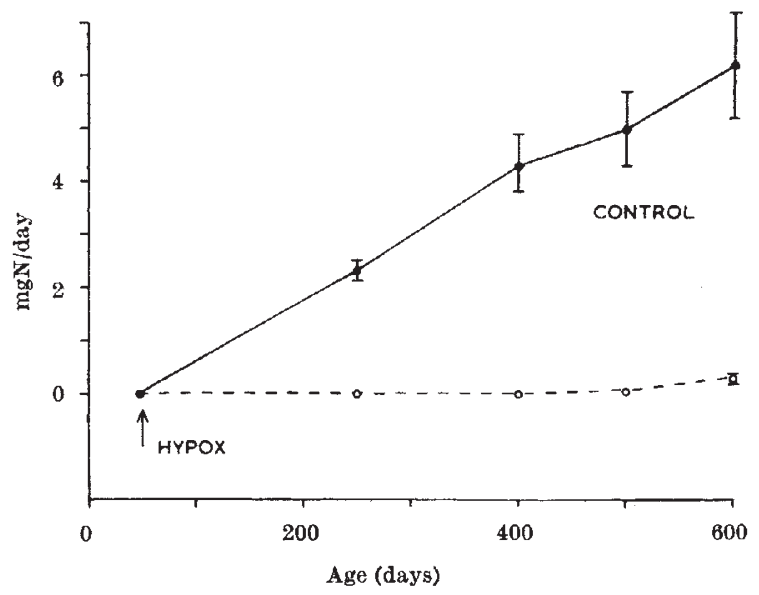

Fig. 1. Variation with age in the daily urinary excretion of protein nitrogen (mean $\pm S . E$.) in 6 male rats hypophysectomized at 50 days of age (broken line) and $\mathbf{2 3}$ controls (continuous line)
3 rats were excreting $0.2,0.4$ and $1.4 \mathrm{mg}$ respectively of protein $\mathrm{N}$ per day; the other 3 hypophysectomized rats in the group were still not excreting any protein.

Seven hypophysectomizod rats died between 500 and 600 days and 4 of these excreted respectively $0 \cdot 1,0 \cdot 2,0 \cdot 5$ and $0.7 \mathrm{mg}$ of protein $\mathrm{N}$ at 500 days. Of 12 hypophysectomized rats which died before 500 days two excreted 0.1 and $0.5 \mathrm{mg}$ respectively of protein $\mathrm{N}$ at 400 days. Thus a total of 16 out of 25 hypophysectomized rats did not excrete detectable amounts of protein in their urine at any stage in their life-cycle. In some of these animals small fragments of pituitary tissue were observed in the pituitary fossa at autopsy. However, this residual tissue did not appear to be correlated with the excretion of protein.

These results, therefore, indicate that hypophysectomy, performed at 50 days of age, delays the onset of proteinuria in the male albino rat until it reaches the age of 400 days or later. This effect of hypophysectomy is similar to that of food restriction, which delays the onset of chronic nephrosis in the rat 4 , as well as slowing the ageing process,

This work was supported by the National Health and Medical Research Council of Australia.

\section{A. V. EVERITT \\ Leanna K. Duvali.}

Department of Physiology,

University of Sydney, Australia.

${ }^{\prime}$ Sellers, A. L., Goodman, H. C., Marmorston, J., and Smith, M., Amer. J. Physiol., 163, 662 (1950).

Linkswiler, H., Reynolds, M. S., and Bauman, C. A., Amer. J. Physiol., 168, 504 (1952).

3 Everitt, A. V., Gerontologia, 2, 33 (1958).

' Saxton, jun., J. A., and Kimball, G. C., Arch. Path., 32, 951 (1941)

'Goodman, H. C., Marmorston, J., Sellers, A. L., Smith, S., and Manders, J., Endocrinology, 49, 490 (1951).

- Everitt, A. V., Gerontologia, 2, 21 (1958).

${ }^{7}$ Henry, R. J., Sobel, C., and Segalove, M., Proc. Soc. Exp. Biol. and Med., 92, $748(1950)$.

\section{Small $\mathrm{pCO}_{2}$ Change and Neuronal Synaptic Activation}

Although the effects of pharmacological and biochemical substances on synaptic activation have been extensively investigated, the influence of $p \mathrm{CO}_{2}$ has received little or no attention ${ }^{1}$. It had been shown previously ${ }^{2}$ that large changes in $p \mathrm{CO}_{2}$ and $p \mathrm{O}_{2}$ altered synaptic activation, and the purpose of the present investigation was to examine quantitatively the effect of small changes in $p \mathrm{CO}_{2}$. Since the impaled mammalian. neurone is extremely fragile, the first investigations, lasting for soveral hours, were performed on a sturdier preparation-the identifiable giant neurones of Aplysia fasciata.

The visceral ganglia of 16 Aplysia fasciata were excised together with their nerves. As previously described ${ }^{2}$ the preparation was investigated in a 2 -ml. 'Lucite' cuvette located in a thermostated cylindrical chamber. The cuvette was filled with sea water and the nerves were mounted on silver chloride-silver hooks connected to a Grass stimulator. Glass micro-electrodes were inserted. into selected nerve cells and, when the preparation was complote, the chamber was covered with a glass plate. Lateral apertures were used for the introduction of microelectrodes and the admission of various gas mixtures so that the chamber could be successively filled with room air or with 5 per cent $\mathrm{CO}_{2}$ in air. Gas flow was regulated by a calibrated flow meter.

The $p \mathrm{H}$ and $p \mathrm{CO}_{2}$ in the blood of Aplysia were determined so that the same levels could be duplicated in vitro in the sea water surrounding the ganglion cells. A few seconds after the molluse had been cut open, samples of blood were taken anaerobically with a tuberculin syringe from the largest vessel leading into the heart. The $p \mathrm{CO}_{2}$, 